KOLOM ILMIAH

Science and Technology

\title{
COOPERATIVE LEARNING TIPE THINK-PAIR-SHARE (TPS) SEBAGAI MODEL PEMBELAJARAN SASTRA (MENGENAL TEKS PUISI)
}

\author{
Eka Haryanti \\ Fakultas Teknik Universitas Teknologi Sumbawa \\ Email: ekaharyanti.uts@gmail.com
}

\begin{abstract}
ABSTRAK
Diterima

Cooperative learning merupakan suatu model pembelajaran yang banyak digunakan

untuk mewujudkan kegiatan belajar mengajar yang berpusat pada siswa (student

Bulan Januari oriented), terutama untuk mengatasi permasalahan yang ditemukan guru dalam 2019 mengaktifkan siswa yang tidak dapat bekerja sama dengan orang lain, siswa yang agresif, dan tidak peduli dengan orang lain. Model cooperative learning akan dapat menumbuhkan pembelajaran efektif yang memiliki ciri, yaitu (a) memudahkan siswa

Diterbitkan belajar se-suatu yang bermanfaat dan (b) pengetahuan, nilai, dan keterampilan diakui oleh Bulan Februari mereka yang berkompeten menilai.

2019

Dalam cooperative learning, terdapat beberapa variasi model yang dapat diterapkan, di antaranya: (a) Jigsaw, (b) Think-Pair-Share, (c) STAD (Student Team Achievement Division), (d) Group Investigation, (e) Two Stay Two Stray, (f) Make a Match, (g)

Kata Kunci: Listening Team, (h) Bamboo Dancing, (i) Inside-Outside Circle, dan (j) The Power of Cooperative Learning, ThinkPair-Share (TPS), Pembelajaran Sastra Two. Think-pair-share yang merupakan variasi model pembelajaran cooperative learning dapat digunakan untuk membantu peserta didik dalam memproduksi karya sastra, khusunya puisi, secara lebih baik. Unsur utama pada model pembelajaran kooperatif tipe think-pair-share adalah tiga tahap utama yang dilaksanakan dalam proses pembelajaran, yaitu tahap think (berpikir secara individual), pair (berpasangan dengan teman), dan share (berbagi jawaban dengan pasangan lain atau seluruh kelas).
\end{abstract}

\section{PENDAHULUAN}

Pembelajaran merupakan upaya pendidik untuk membantu peserta didik melakukan kegiatan belajar (Isjoni, 2010:11). Tujuan pembelajaran ini adalah terwujudnya efisiensi, efektifitas, dan keoptimalan kegiatan belajar yang dilakukan peserta didik. Dalam mencapai tujuan pembelajaran tersebut, dibutuhkan petunjuk, paradigma, atau teori yang digunakan untuk memandang, menginterpretasi, dan memahami aspek-aspek kehidupan.

Penemuan dalam bidang ilmu pengetahuan melibatkan suatu pemisahan dari paradigma lama atau tradisional. Sebagai contoh, Ptomeleus, pakar astronomi terkemuka dari Mesir, meyakinkan dunia bahwa bumi adalah pusat segalanya. Namun, Nikolaus Kopernikus mengubah paradigma ini dengan pernyataan bahwa mataharilah yang menjadi pusat planet-planet (Lie, 2010:2). Dengan demikian, paradigma baru tersebut dapat mengubah interpretasi dunia.

Dalam dunia pendidikan, paradigma lama memandang bahwa proses belajar mengajar bersumber pada pendidik. Pikiran anak dianggap kosong dan harus diisi, seperti menuangkan air ke dalam gelas kosong. Dengan kata lain, segala ilmu pengetahuan dan kebijaksanaan berasal dari pendidik. Dengan paradigma tradisional tersebut, tidak akan terwujud efisiensi, efektifitas, dan keoptimalan kegiatan belajar yang dilakukan oleh peserta didik. Maka dari itu, cooperative learning sebagai paradigma baru muncul sebagai pembaruan untuk mewujudkan efisiensi, efektifitas, dan keoptimalan kegiatan belajar yang dipusatkan kepada siswa.

Cooperative learning pertama kali dikembangkan untuk mengurangi kompetisi di sekolah-sekolah Amerika yang diidentifikasi oleh James Coleman sebagai komponen negatif dari sistem pendidikan. Keberhasilan cooperative learning dalam rangka mengoptimalkan pembelajaran yang berpusat pada siswa (student centered) dan mengurangi tingkat kompetisi tersebut membuat cooperative learning digunakan sebagai paradigma baru dalam dunia pendidikan dunia, termasuk Indonesia.

Menurut Suprijono (2010:55), dukungan teori konstruktivisme sosial Vygotsky telah meletakkan arti penting model pembelajaran kooperatif (cooperative learning). Konstruktivisme sosial Vygotsky menekankan bahwa pengetahuan dibangun dan dikonstruksi secara mutual. Keterlibatan 


\section{JURNAL TAMBORA}

\section{Vol. 3 No. 1 Februari 2019}

dengan orang lain membuka kesempatan bagi mereka mengevaluasi dan memperbaiki pemahaman. Vygotsky juga menekankan peserta didik mengonstruksi pengetahuan melalui interaksi sosial dengan orang lain.

\section{HASIL DAN PEMBAHASAN}

\section{A. Pengertian Cooperative Learning}

Cooperative learning berasal dari kata cooperative yang artinya mengerjakan sesuatu secara bersama-sama dengan saling membantu satu sama lainnya sebagai satu kelompok atau satu tim (Isjoni, 2010:15). Cooperative learning merupakan suatu model pembelajaran yang banyak digunakan untuk mewujudkan kegiatan belajar mengajar yang berpusat pada siswa (student oriented), terutama untuk mengatasi permasalahan yang ditemukan guru dalam mengaktifkan siswa yang tidak dapat bekerja sama dengan orang lain, siswa yang agresif, dan tidak peduli dengan orang lain. Dari uraian tersebut, dapat dikemukakan bahwa coope-rative learning adalah suatu model pembelajaran kelompok yang digunakan oleh guru untuk melibatkan siswa secara aktif dalam melakukan kegiatan belajar agar kemampuan belajarnya semakin meningkat.

Menurut Nurhadi (2004:60), cooperative learning memerlukan pendekatan pembelajaran melalui penggunaan kelompok kecil siswa yang bekerja sama dalam memaksimalkan kondisi belajar guna mencapai tujuan bersama. Selanjutnya, Isjoni (2009:20) menegaskan bahwa dalam pembelajaran cooperative learning, sebaiknya kelompok dibentuk secara heterogen. Maksudnya, siswa yang memiliki kepandaian lebih tinggi dari pada teman yang lain mampu memberikan bantuan kepada teman yang memiliki kemampuan di bawahnya. Hal ini akan menjadikan siswa yang memiliki kemampuan kurang dapat memahami pelajaran dan meng-ikuti pelajaran dengan baik.

Salah satu ciri yang dimiliki oleh semua kelompok yaitu adanya interaksi dari setiap anggota dan saling memberikan pengaruh satu dengan yang lain. Menurut Suprijono (2010:57), kelompok bukanlah semata-mata sekumpulan orang. Kumpulan disebut kelompok apabila ada interaksi, mempunyai tujuan, berstruktur, dan groupness. Interaksi adalah saling memengaruhi individu satu dengan yang lain, interaksi tersebut dapat berlangsung secara fisik, nonverbal, emosional, dan sebagainya. Tujuan dalam kelompok dapat bersifat intrinsik dan ekstrinsik. Tujuan intrinsik adalah tujuan yang didasarkan pada alasan bahwa dalam kelompok perasaan menjadi senang, sedangkan tujuan ekstrinsik adalah tujuan yang didasarkan pada alasan bahwa untuk mencapai sesuatu tidak dapat dicapai secara sendiri, melainkan harus dikerjakan secara bersama-sama. Struktur kelompok menunjukkan bahwa dalam kelompok terdapat peran, peran dari tiap-tiap individu atau anggota kelompok berkaitan dengan posisi individu masing- masing. Setiap anggota kelompok berinteraksi berdasarkan peran-perannya seba-gaimana norma yang mengatur perilaku anggota kelompok. Groupness menunjukkan bahwa kelompok merupakan suatu kesatuan. Kelompok bukanlah semata-mata kumpulan orang yang saling berdekatan. Kelompok adalah kesatuan yang bulat di antara anggotanya.

Cooperative learning tidak sama dengan sekadar belajar dalam kelompok (Suprijono, 2010:58). Ada unsur-unsur dasar cooperative learning yang membe-dakannya dengan pembagian kelompok yang dilakukan secara asal-asalan. Pelaksanaan prosedur model cooperative learning dengan benar akan memungkinkan guru mengelola kelas lebih efektif. Kelompok yang dibentuk dalam cooperative learning ini adalah kelompok kecil beranggotakan empat hingga enam siswa agar kerja kelompok berjalan secara lebih efektif. Selanjutnya, menurut Suprijono (2010:61), keefektifan kerja kelompok menciptakan suasana pembelajaran yang menyenangkan, di mana semua siswa dapat berperan aktif, bersemangat dalam be-lajar, dan berani mengutarakan pendapat dalam kelompok masing-masing. Dalam cooperative learning, guru berperan sebagai fasilitator yang tidak hanya memberikan ceramah dan komunikasi satu arah saja. Oleh karena itu, guru dapat mem-berikan kebebasan dan keleluasaan kepada siswa untuk mengembangkan kompe-tensi siswa.

\section{B. Karakteristik Pembelajaran Cooperative Learning}

Cooperative learning tidak sama dengan sekadar belajar dalam kelompok (Suprijono, 2010:58). Model cooperative learning akan dapat menumbuhkan pembelajaran efektif yang memiliki ciri, yaitu (a) memudahkan siswa belajar se-suatu yang bermanfaat dan (b) pengetahuan, nilai, dan keterampilan diakui oleh mereka yang berkompeten menilai.

Roger dan David (dalam Suprijono, 2010:58) mengatakan bahwa tidak se-mua belajar kelompok bisa dianggap sebagai pembelajaran kooperatif (coopera-tive learning). Untuk mencapai hasil maksimal, terdapat lima unsur yang harus diterapkan dalam model pembelajaran kooperatif. Unsur-unsur tersebut yaitu: (1) positive interdependence (saling ketergantungan positif), (2) personal respon-bility (tanggung jawab perseorangan), (3) face to face promotitive interaction (in-teraksi promotif), (4) interpersonal skill (komunikasi antaranggota), dan (5) gro-up processing (pemrosesan kelompok).

Model pembelajaran cooperative learning dikembangkan untuk mencapai hasil belajar yang berupa prestasi akademik, toleransi, menerima keragaman, dan pengembangan keterampilan sosial. Untuk mencapai hasil belajar itu, model pembelajaran cooperative learning menuntut kerja sama 


\section{JURNAL TAMBORA}

\section{Vol. 3 No. 1 Februari 2019}

dan adanya hubungan saling ketergantungan peserta didik dalam struktur tugas struktur tujuan, dan struktur re-ward-nya. Struktur tugas berhubungan dengan bagaimana pengorganisasian tugas. Struktur tujuan dan reward mengacu pada derajat kerja sama atau kompetisi yang dibutuhkan untuk mencapai tujuan maupun reward.

Lungdren dalam Jauhar (2011:53) memaparkan unsur-unsur dasar cooperative learning, yakni:

a) siswa harus memiliki persepsi bahwa mereka "tenggelam bersama dan tenggelam bersamasama",

b) siswa harus memiliki tanggung jawab pada diri sendiri dalam mempelajari materi yang dihadapi dan tanggung jawab terhadap siswa lain dalam kelompoknya,

c) siswa harus berpandangan bahwa mereka memiliki tujuan yang sama,

d) siswa membagi tugas dan tanggung jawab,

e) siswa diberikan satu evaluasi pada anggota yang berpengaruh terhadap evaluasi kelompok,

f) siswa berbagi kepemimpinan sementara mereka memperoleh keterampilan bekerja sama selama belajar, dan

g) setiap siswa akan diminta mempertanggungjawabkan secara individu materi yang ditangani dalam kelompok kooperatif.

\section{Model-model Cooperative Learning}

Model pembelajaran adalah suatu pola atau rencana yang sudah direncanakan sedemikian rupa dan digunakan untuk menyusun kurikulum, mengatur materi pelajaran, dan memberi petunjuk kepada pengajar di kelasnya (Isjoni, 2010:50). Dalam penerapannya, model pembelajaran ini harus sesuai dengan kebutuhan siswa. Dalam cooperative learning, terdapat beberapa variasi model yang dapat diterapkan, di antaranya: (a) Jigsaw, (b) Think-Pair-Share, (c) STAD (Student Team Achievement Division), (d) Group Investigation, (e) Two Stay Two Stray, (f) Make a Match, (g) Listening Team, (h) Bamboo Dancing, (i) Inside-Outside Circle, dan (j) The Power of Two.

\section{Think-Pair-Share}

Think-pair-share merupakan salah satu tipe pembelajaran kooperatif yang dikembangkan oleh Frank Lyman dan rekan-rekannya dari Universitas Maryland pada tahun 1985 sebagai salah satu struktur kegiatan cooperative learning (Isjoni, 2010:78). Think-pair-share memberikan waktu kepada para siswa untuk berpikir, merespon, dan saling membantu satu sama lain sehingga model ini memiliki potensi kuat untuk memberdayakan dan meningkatkan kemampuan berpikir siswa, serta dapat meningkatkan hasil belajar atau prestasi belajar siswa. Selain itu, think-pair-share juga memberi siswa kesempatan untuk bekerja sendiri serta bekerja sama dengan orang lain.

\section{a. Unsur-unsur Think-Pair-Share dalam Pembelajaran Sastra (Mengenal Teks Puisi)}

Unsur utama pada model pembelajaran kooperatif tipe think-pair-share adalah tiga tahap utama yang dilaksanakan dalam proses pembelajaran, yaitu tahap think (berpikir secara individual), pair (berpasangan dengan teman), dan share (berbagi jawaban dengan pasangan lain atau seluruh kelas).

1) Think (berpikir secara individual)

Berpikir merupakan salah satu unsur utama dalam model cooperative learning tipe think-pairshare. Pada tahap think, guru mengajukan suatu pertanyaan atau masalah yang dikaitkan dengan pelajaran, kemudian siswa diminta untuk berpikir secara mandiri mengenai pertanyaan atau masalah yang diajukan. Pada tahapan ini, siswa sebaiknya menuliskan jawaban mereka. Hal ini karena guru tidak dapat memantau semua jawaban siswa sehingga melalui catatan tersebut guru dapat mengetahui jawaban yang harus diperbaiki atau diluruskan di akhir pembelajaran. Dalam menentukan batasan waktu untuk tahap ini, guru harus mempertimbangkan pengetahuan dasar siswa untuk menjawab pertanyaan yang diberikan, jenis dan bentuk pertanyaan yang diberikan, serta jadwal pembelajaran untuk setiap kali pertemuan.

Kelebihan dari tahap ini adalah adanya think time atau waktu berpikir yang memberikan kesempatan kepada siswa untuk berpikir mengenai jawaban mereka sendiri sebelum pertanyaan tersebut dijawab oleh siswa lain. Selain itu, guru dapat mengurangi masalah dari adanya siswa yang mengobrol, karena tiap siswa memiliki tugas untuk dikerjakan sendiri.

\section{2) Pair (berpasangan dengan teman)}

Unsur kedua dalam think-pair-share terdapat pada tahap pair (berpasangan). Pada tahap ini, guru meminta para siswa untuk berpasangan atau dapat berkumpul dalam kelompok-kelompok kecil untuk mendiskusikan materi yang telah dipikirkan. Interaksi selama periode ini dapat menghasilkan jawaban bersama. Biasanya guru mengizinkan tidak lebih dari 4 atau 5 menit untuk berpasangan. Setiap pasangan siswa saling berdiskusi mengenai hasil jawaban mereka sebelumnya sehingga hasil akhir yang didapat menjadi lebih baik, karena siswa mendapat tambahan informasi dan pemecahan masalah yang lain.

3) Share (berbagi jawaban dengan pasangan lain atau seluruh kelas)

Share merupakan unsur utama ketiga dalam pelaksanaan think-pair-share. Pada tahap ini, guru meminta pasangan-pasangan atau kelompokkelompok tersebut tersebut untuk berbagi hasil pemikiran mereka dengan pasangan lain, kelompok lain, dan atau dengan seluruh kelas. Pasangan lain dan siswa dalam kelas dapat saling mengoreksi 


\section{JURNAL TAMBORA}

Vol. 3 No. 1 Februari 2019

pekerjaan dan mengungkapkan pendapat yang membangun agar hasil tulisan menjadi lebih baik. Pada tahap ini, siswa atau kelompok lain juga dapat mengajukan beberapa pertanyaan jika terdapat beberapa hal yang kurang dipahami. Akan menjadi lebih efektif jika pada tahap ini guru berkeliling kelas dari pasangan satu ke pasangan yang lain sehingga seluruh siswa memiliki kesempatan untuk melaporkan tugasnya. Tahap ini merupakan penyempurnaan dari tahap-tahap sebelumnya, dalam arti bahwa tahap ini menolong agar semua kelompok menjadi lebih paham mengenai pemecahan masalah yang diberikan berdasarkan penjelasan kelompok yang lain. Hal ini juga agar siswa benar-benar mengerti ketika guru memberikan koreksi maupun penguatan di akhir pembelajaran (Widarti, 2007:22-26).

\section{b. Cooperative Learning Tipe Think-Pair- Share dalam Pembelajaran Sastra}

Pengajaran sastra membawa siswa pada ranah produktif dan apresiatif. Sastra adalah sistem tanda karya seni yang bermediakan bahasa. Pencipataan karya sastra merupakan keterampilan dan kecerdasan intelektual dan imajinatif. Karya sastra hadir untuk dibaca, dinikmati, dan dimanfaatkan untuk mengembangkan wawasan kehidupan.

Pembelajaran sastra perlu menekankan pada kenyataan bahwa sastra merupakan seni yang dapat diproduksi dan diapresiasi sehingga pembelajaran hendaknya bersifat produktif-apresiatif (Sutejo, 2009:7). Dalam pembelajaran, karya sastra dapat diproduksi dengan baik oleh peserta didik, khususnya menulis puisi. Hal tersebut akan lebih baik juga jika model pembelajaran yang digunakan dalam kelas benar-benar dapat membantu peserta didik untuk lebih berpikir secara kreatif dan imajinatif dalam memproduksi karya sastra. Thinkpair-share yang merupakan variasi model pembelajaran cooperative learning dapat digunakan untuk membantu peserta didik dalam memproduksi karya sastra, khususnya puisi, secara lebih baik.

\section{c. Langkah-langkah Think-Pair-Share dalam Pembelajaran Mengenal Teks Puisi}

Beberapa langkah dalam pelaksanaan model cooperative learning tipe think-pair-share dalam pembelajaran mengenal teks puisi yakni:

a) guru memberikan tema tentang alam semesta kepada siswa,

b) siswa memikirkan (think) dan mengumpulkan kata-kata yang akan dijadikan larik-larik puisi,

c) guru membentuk kelas menjadi beberapa kelompok atau siswa dapat berkelompok dengan teman sebangkunya (pair),

d) masing-masing siswa dalam kelompok dapat memberikan masukan dan menyumbangkan kata-kata baru untuk dapat didiskusikan dan dijadikan larik-larik puisi, e) masing-masing siswa dalam kelompok menuliskan puisi berdasarkan kata-kata yang telah terkumpul,

f) siswa dapat berbagi jawaban (puisi yang telah dibuat) kepada guru dan seluruh teman (share), dan

g) guru serta siswa yang lain memberikan masukan atau pendapat agar puisi yang telah ditulis menjadi lebih baik.

\section{Keunggulan dan Kelemahan Cooperative Learning Tipe Think-Pair-Share}

Secara umum, terdapat beberapa keunggulan dari metode cooperative learning. Pertama, metode ini dapat menambah kepercayaan kemampuan berpikir sendiri, menemukan informasi dari berbagai sumber, dan belajar dari siswa yang lain. Kedua, dengan belajar berkelompok seperti ini, siswa dapat mengembangkan kemampuan menngungkapkan ide atau gagasan dengan kata-kata secara verbal dan membandingkannya dengan ideide orang lain. Akhirnya, metode ini dapat membantu anak respek pada orang lain, menyadari keterbatasan serta menerima segala perbedaan.

Beberapa keunggulan juga terdapat dalam metode cooperative learning tipe think-pair-share. Menurut Widarti (2007:37), keunggulankeunggulan tersebut adalah sebagai berikut.

a) Para siswa menggunakan waktu lebih banyak untuk mengerjakan tugasnya dan untuk mendengarkan pendapat satu sama lain ketika mereka terlibat dalam kegiatan think-pairshare. Selain itu, akan ditemukan lebih banyak siswa yang mengangkat tangan mereka untuk bertanya dan menjawab pertanyaan setelah berlatih kelompoknya. Para siswa akan lebih mengingat apa yang akan ditanyakan atau dijawab seiring dengan penambahan waktu tunggu dan kualitas jawaban siswa juga akan menjadi lebih baik.

b) Para guru juga mempunyai waktu yang lebih banyak untuk berpikir ketika menggunakan think-pair-share. Mereka dapat berkonsentrasi mendengarkan jawaban siswa, mengamati reaksi siswa, dan mengajukan pertanyaan tingkat tinggi.

Keunggulan lain dari think-pair-share menurut Isjoni (2010:78), yaitu optimalisasi partisipan siswa dengan memberi kesempatan delapan kali lebih banyak kepada setiap siswa untuk dikenali dan menunjukkan partisipasi mereka kepada orang lain. Di balik semua kelebihan model pembelajaran tersebut, metode ini juga memiliki beberapa kelemahan. Menurut Lie (2010:35), kekurangan model pembelajaran ini adalah (a) tidak selamanya mudah bagi siswa untuk mengatur cara berpikir sistematik; (b) lebih sedikit ide yang masuk; dan (c) jika ada perselisihan, tidak ada penengah dari siswa dalam kelompok yang bersangkutan sehingga 
banyak kelompok yang melapor dan perlu dimonitor.

Di samping itu, beberapa kelemahan lain dari model pembelajaran think-pair-share adalah sebagai berikut.

a) Membutuhkan waktu lama dan sulit melakukan penilaian.

b) Membutuhkan koordinasi secara bersamaan dari berbagai aktivitas.

c) Membutuhkan perhatian khusus dalam penggunaan ruangan kelas.

d) Peralihan dari seluruh kelas ke kelompok kecil dapat menyita waktu pengajaran yang berharga. Untuk itu, guru harus dapat membuat perencanaan yang saksama, sehingga dapat meminimalkan jumlah waktu yang terbuang.

e) Menggantungkan pada pasangan.

f) Jumlah siswa yang ganjil berdampak pada saat pembentukan kelompok, karena ada satu siswa tidak mempunyai pasangan.

g) Ketidaksesuaian antara waktu yang direncanakan dengan pelaksanaannya.

h) Metode pembelajaran think-pair-share belum banyak diterapkan di sekolah.

i) Sangat sulit diterapkan di sekolah yang ratarata kemampuan siswanya rendah.

j) Menyusun bahan ajar setiap pertemuan dengan tingkat kesulitan yang sesuai dengan taraf berfikir anak.

\section{PENUTUP}

\section{Kesimpulan}

Cooperative learning muncul sebagai pembaruan dari pandangan atau perspektif lama mengenai pembelajaran yang berpusat pada guru (teacher oriented). Cooperative learning sebagai model pembelajaran berkelompok yang tidak sekadar berkelompok, namun masing-masing dari anggota kelompok memiliki tanggung jawab dan tugas untuk mencapai keberhasilan pembelajaran. Cooperative learning yang memiliki banyak variasi model, termasuk di dalamnya think-pair-share dapat digunakan dalam pembelajaran sastra, khususnya menulis puisi. Meskipun demikian, masih terdapat kelemahan dari model pembelajaran ini karena membutuhkan waktu yang lama, penilaian yang sulit, kontrol siswa yang tidak mudah, dan lain-lain.

\section{REFERENSI}

Isjoni. 2009. Cooperative Learning: Meningkatkan Kecerdasan Komunikasi Antar Peserta Didik. Yogyakarta: Pustaka Pelajar.

Isjoni. 2010. Cooperative Learning: Efektifitas Pembelajaran Kelompok. Ban-dung: Alfabeta.
Jauhar, Mohammad. 2011. Implementasi PAIKEM: dari Behavioristik sampai Konstruktivistik. Jakarta: Prestasi Pustakarya.

Lie, Anita. 2010. Cooperative Learning: Mempraktikkan Cooperative Learning di Ruang-Ruang Kelas. Jakarta: Grasindo.

Nurhadi. 2004. Pembelajaran Contextual (Contextual Teaching and Learn-ing/CTL) dan Penerapannya dalam KBK. Malang: Universitas Negeri Malang.

Suprijono, A. 2010. Cooperative Learning: Teori \& Aplikasi Paikem. Yogyakarta: Pustaka Pelajar.

Sutejo. 2009. Teknik Kreativitas Pembelajaran. Surabaya: Lentera Cendikia.

Widarti, A. 2007. Efektivitas Penggunaan Model Pembelajaran Kooperatif Tipe Think-PairShare Terhadap Hasil Belajar Pokok Bahasan Segi Empat Pada Siswa Kelas VII Semester 2

(Online), (http://digilib.unnes.ac.id/gsdl/cgibin/library) diakses 14 April 2018. 